\title{
K POJETÍ A ČLENĚNÍ FOREM SPRÁVNÍ ČINNOSTI PO 40 LETECH
}

\author{
JOSEF STAŠA
}

Abstract: On the Concept and Division of Administrative Activity Forms after 40 Years

The administrative activity forms are defined as groups of relatively homogeneous public law actions of public administrators. Their distribution is the result of the cascading application of several classification criteria. This approach was presented in Czech literature exactly just 40 years ago. In the new social conditions both doctrine changes and terminological changes occurred. Doctrinal knowledges had a practical impact on the formulating of valid Code of Administrative Procedure. At present, theory describes abstract acts, measures of a general nature, administrative acts, factual interferences, public contracts and non-regulatory actions as administrative activity forms. The suitability of complementing the cascading approach to the division of forms of administrative activity by the matrix approach is turning out. It is appropriate to discuss the relation between the material and formal concepts of some administrative activity forms. There is also the possibility of a broader conception of administrative activity by including some private law negotiations.

Keywords: public administration; administrative activity forms; abstract act; measure of a general nature; administrative act; factual interference; public contract; non-regulatory action

Klíčová slova: veřejná správa; formy správní činnosti; abstraktní akt; opatření obecné povahy; správní akt; faktický zásah; veřejnoprávní smlouva; neregulativní úkon

DOI: $10.14712 / 23366478.2020 .8$

\section{MALÉ OHLÉDNUTÍ}

Je tomu 40 let, co naše novější teorie správního práva dospěla ke komplexnějšímu zobecňujícímu pohledu na hmotněprávní stránku správní činnosti, když oprášila ${ }^{1}$ pojem „formy správní činnosti“ a pokusila se naznačit jejich klasifikaci.

V r. 1980 byla publikována monografie B. Voženílka, ${ }^{2}$ věnovaná této problematice, která byla výsledkem několikaletého „mapování“ předmětné materie³.

1 Ve starší (předválečné) teorii použil tohoto označení představitel vídeňské školy správního práva A. MERKL (Allgemeines Verwaltungsrecht, Wien/Berlin: J. Springer, 1927). Dílo bylo přeloženo do češtiny a vydáno v letech 1931-1932.

2 VOŽENÍLEK, B. K pojetí a klasifikaci forem správní činnosti. Acta Universitatis Carolinae - Iuridica, 1980, roč. 26, č. 2. I když jde o pouhou shodu okolností, lze aktuální číslo AUC vnímat jako jubilejní.

3 Voženílkovy články publikované v časopisu Správní právo od r. 1974. 
Téhož roku byl dokončen rukopis první česky psané poválečné učebnice správního práva, ${ }^{4} \mathrm{v}$ níž se otázkám forem správní činnosti (v tehdejším dobovém kontextu pod nadpisem „formy státní správy“) věnoval Z. Červený. ${ }^{5}$

Dosažený výsledek dobře ilustruje následující citace: ${ }^{6}$

„Státní správa má svioj konkrétní, právem stanovený obsah. Obsah však musí mít určitou formu, to znamená svioj vnějš́ výraz.

Státni správa se navenek projevuje v konkrétnich úkonech správnich orgánů. Správní úkony jsou tedy vnějšim výrazem obsahu státní správy. V nich se státní správa materializuje. Tyto úkony mají různorodý charakter a sleduji různý konkrétni účel a cíl, všem je však společné, že správní orgány jimi prakticky realizují svou kompetenci.

Při bližšim zkoumání zjistime, že v celkovém souhrnu správních úkonů jsou úkony vnitřni podstatou shodné nebo př́buzné, úkony, které se vyznačuji stejnými společnými znaky a které tak tvoři relativně samostatné skupiny stejnorodých správnich úkonů.

Tyto skupiny správnich úkonů označujeme jako formy státni správy.“

Autor dále konstatuje absenci všeobecně uznávané klasifikace forem správní činnosti a nastiňuje klasifikaci pomocí více kritérií. ${ }^{7}$ Postupně „nasazuje“ kritérium povahy právních důsledků (to vede $\mathrm{k}$ rozlišení právotvorných a neprávotvorných úkonů), kritérium jednostrannosti/vícestrannosti (to vede $\mathrm{k}$ rozlišení právotvorných úkonů na správní akty a správní dohody), kritérium právních vlastností (to vede k rozlišení správních aktů na normativní a individuální) a existence/neexistence povinnosti podř́dit se úkonu (to vede $\mathrm{k}$ rozlišení neprávotvorných úkonů na materiálně technické a společenskoorganizátorské). ${ }^{8}$

Přes odlišnost doby je uvedený př́istup $\mathrm{k}$ vymezení a členění forem správní činnosti vlastní i současné české doktríně. Platí, že:

- formy správní činnosti jsou vymezovány jako stejnorodé skupiny správních úkonů modelované na značně vysokém stupni obecnosti,

- členění forem správní činnosti lze v prvním plánu odvíjet od kaskádovitého použití několika klasifikačních kritérií.

Výrazné změny, jimiž doktrína prošla, přirozeně souvisejí jak se zvratem domácích společenských poměrů (pád totality), tak s nadnárodními či globálními vývojovými trendy - (modernizace veřejné správy).

$Z$ věcného hlediska má prvořadý význam:

- vytvoření ústavního rámce uplatňování veřejné moci v prostředí demokratického právního státu, limitující uplatňování vrchnostenských forem správní činnosti,

- prosazování principu dobré správy, vedoucí k utváření prostředí umožňujícího rozvoj nevrchnostenských forem správní činnosti,

- deetatizace spočívající v decentralizaci veřejné správy, inspirující uplatňování dalšího kritéria klasifikace správní činnosti,

4 LUKEŠ, Z. a kol. Československé správni právo. Obecná část. Praha: Panorama, 1981.

5 V téže publikaci pojednává o formách státní správy v jiném kontextu Z. Lukeš (s. 142-149). K odlišnému členění dospívá při jejich charakteristice coby projevů metod státní správy.

6 ČERVENÝ, Z. In: LUKEŠ. Z a kol., c. d., s. 149-150. Citováno s vynecháním poznámek pod čarou (= př́íklady úkonů $\mathrm{z}$ tehdejší praxe).

7 Tamtéž, s. 150.

8 Tamtéž, s. 151-152. 
- deetatizace spočívající v substituci aktivit osob veřejného práva veřejnoprávně významnými aktivitami autorizovaných osob soukromého práva ${ }^{9}$, potenciálně prolamující chápání forem správní činnosti jako právních úkonů veřejnoprávní povahy.

Členění správní činnosti bylo a je relativizováno jak (od počátku) parciálně, tak (posléze) globálně.

Parciálně tím, že hranice mezi některými tradičními formami správní činnosti se „odjakživa“ doktrinálně jevila jako neostrá. Projevilo se to ve vztahu (za použití terminologie zmíněné klasifikace ${ }^{10}$ ) normativních správních aktů a individuálních správních aktů. Zmínky o nejasnosti tohoto rozhraní v odborné literatuře nedávno stručně shrnul D. Hejč. ${ }^{11}$

Posléze tím, že postupem času začaly v souvislosti se zaváděním inovativních právních institutů $\mathrm{v}$ té či oné míře ztrácet pevné obrysy téměř všechny výše zmíněné formy správní činnosti. Sledování této tendence ztěžuje fakt, že v 80. letech, v intencích tehdejších představ o roli státu a práva, nebyl reálný otisk některých doktrinálně fabulovaných forem správní činnosti v pozitivním právu zřetelný. Hodnocení vývoje v 90. letech zase zkresluje skutečnost, že správněprávní úpravy byly zejména v tomto desetiletí v řadě ohledů ovlivněny prvorepublikovými schématy. Je ale patrné, že v zemích, kde se správní právo vyvíjelo kontinuálně, se tato tendence projevila dřive než u nás. Otázku možných posunů při uplatňování forem správní činnosti a vzniku nových forem správní činnosti cca před 25 lety v 1 . vydání pražské učebnice správního práva zmínil D. Hendrych. ${ }^{12}$

Pozornost ovšem zasluhuje i stránka terminologická.

Pojem „forma státní správy“ byl nahrazen pojmem „forma správní činnosti“, nicméně zpočátku s určitou opatrností, kterou bylo lze vycítit z preferování pojmů ,právní jednání veřejné správy“13 nebo „právní úkon veřejné správy“14. V pražské učebnici správního práva se spojení „formy správní činnosti“ objevuje od 2 . vydání. ${ }^{15}$

Změny terminologie se týkaly zejména jednotlivých forem správní činnosti a k některým přistoupila pouze část nauky ${ }^{16}$. Zatímco brněnská škola dodnes setrvala na někdejším označení jednostranných právotvorných úkonů, nahradila pražská škola v 90 . letech termín normativní správní akt termínem ,abstraktní akt"17 a termín individuální správní akt termínem „správní akt“ (bez dalšího př́vlastku) ${ }^{18}$; z obsahového hlediska tento rozdílný př́stup význam nemá; objevil se i pokus o zavedení polopatičtější označení

\footnotetext{
9 Tato tendence svědčí, kromě jiného, o překonávání vyhraněného pojetí právního dualismu.

10 O terminologii viz níže.

11 HEJČ, D. Smíšené správní akty v právním řádu ČR anebo 10 let účinnosti opatření obecné povahy. Právník, 2016, roč. 155, č. 10, s. 829-842.

12 HENDRYCH, D. In: HENDRYCH, D. a kol. Správní právo. Obecná část. 1. vyd. Praha: C. H. Beck / SEVT, 1994, s. 54.

13 BAŽIL, Z. - ČEBIŠOVÁ, T. - HENDRYCH, D. - PRÁŠKOVÁ, H. - STAŠA, J. - VOPÁLKA, V. Správní právo. Texty II. Praha: Aleko, 1991.

14 STAŠA, J. Úvod do českého správnihho práva. 1. vyd. Praha: Policejní akademie České republiky ČR, 1994, s. 50 a násl.

15 HENDRYCH, D. in HENDRYCH, D. a kol. Správní právo. Obecná část. 2. vyd. Praha: C. H. Beck, 1996, s. 53.

16 Rozdílně se začaly rozvíjet její pražská a brněnská větev.

17 Od cit. 2. vydání pražské učebnice. Viz s. 55 a násl.

18 Stalo se tak o něco dříve než v předchozím případě. V cit. 1. vydání pražské učebnice viz s. 54 a násl.
} 
abstraktních aktů (správní předpisy) ${ }^{19}$. Pro správní dohody se již v 90 . letech vžilo označení veřejnoprávní smlouvy. Vývoj na hraně terminologického bloudění prodělalo označení nepravotvorných úkonů (od ,jiných právně významných správních úkonů“ “ $[\mathrm{v} 1$. vydání pražské učebnice] ${ }^{20}$ přes ,,právně nezávazné správní úkony“ [její 2. vydání], ${ }^{21}$,jiné úkony“ [od jejího 3. vydání],22 až po dnešní „neregulativní úkony“ [v jejím 9. vydání] ${ }^{23}$ ).

Ohledně členění správní činnosti docházelo počínaje 90 . léty přinejmenším ke čtyřem změnám doktríny.

Za prvé: Zesílil pocit potřeby učinit si zřetelnější představu o již zmíněném prostoru mezi normativními/abstraktními akty a individuálními/konkrétními akty (resp. správními akty v „novém“ smyslu slova ${ }^{24}$ ). Objevují se pojmy „hybridní správní úkon“25 nebo „obecně konkrétní akt“26 (pozdějii27 „abstraktně konkrétní akt“) a pokusy o jejich demonstraci, popřípadě i ucelenější charakteristiku.

Za druhé: Z okruhu individuálních/konkrétních aktů (správních aktů) doktrína vydělila nejprve úkony označované jako „bezprostřední zákroky“, ${ }^{28}$ později „,bezprostřední zásahy“ jako podskupinu „,donucovacích úkonü“ ${ }^{29}$ resp. „faktických donucovacích úkonů“ ${ }^{30}$ a posléze „,faktických pokynů a donucovacích úkonů“,31 resp. „faktických zásahů“32 či „faktických úkonů (reálných aktů)“333. Vznikla tak další „,samostatná“ forma správní činnosti. Stalo se to v důsledku doplnění klasifikační kaskády o kritérium stupně formalizace úkonu.

Za třetí: Prohloubilo se a diferencovalo doktrinální chápání správních dohod, resp. veřejnoprávních smluv. S využitím zahraniční (německé) inspirace byl formulován institut subordinační veřejnoprávní smlouvy jako alternativy správního aktu. ${ }^{34}$

Za čtvrté: U vědomí dobové podmíněnosti někdejšího členění doktrína rezignovala na systematickou klasifikaci neprávotvorných/neregulativních úkonů (uplatnění shora

19 STAŠA, J., c. d., s. 53 a násl.

20 V cit. 1. vydání na s. 79-84. Ve stejné době u J. Staši (c. d., s. 65 a násl.) „ostatní správní úkony“.

21 V cit. 2. vydání na s. 99-107.

22 HENDRYCH, D. a kol. Správní právo. Obecná část. 3. vyd. Praha: C. H. Beck, 1998, s. 115-122.

23 HENDRYCH, D. a kol. Správní právo. Obecná část. 9. vyd. Praha: C. H. Beck, 2016, s. 191-200. Již dříve („,neregulativní správní úkony“) STAŠA, J. Úvod do českého správního práva. 4. vyd. Praha: Policejní akademie České republiky, 2001, s. 92-94.

24 Ve skutečnosti nikoli novém, nýbrž resuscitovaném. Srov. např. HOETZEL, J. Československé správní právo. Č́st všeobecná. Praha: Melantrich, 1934, s. 240-245.

25 STAŠA, J., c. d., 1. vydání, s. 61-62. Označení jejich podskupin jako „nepravé správní předpisy“ a „nepravé správní akty“ navazuje na rozlišení tzv. nepravých normativních aktů, jejichž obsah neodpovídá zákonem předepsané formě právního předpisu (neobsahují normy), a tzv. quasiindividuálních aktů, které jsou vydávány v situaci konkretizující právní normu, ale nesplňují požadavek adresnosti (viz GERLOCH, A. - STAS̆A, J. - TROJAN, K. Dialektický charakter pramenů práva v kontextu socialistické zákonnosti a efektivnosti práva. Právny obzor, 1985, roč. 68, č. 3, s. 261-274).

${ }^{26} \mathrm{~V}$ cit. 2. vydání pražské učebnice na s. 57 jako reflexe zahraničních tzv. všeobecných opatření.

27 HENDRYCH, D. a kol. Správní právo. Obecná část. 7. vyd. Praha: C. H. Beck, 2009, s. 191.

28 STAŠA, J., c. d., 1. vydání, s. 62-63.

29 V cit. 2. vydání pražské učebnice na s. 95-97.

30 STAS̆A, J. Úvod do českého správního práva. 2. vyd. Praha: Policejní akademie České republiky, 1996, s. 85 a násl.

31 V cit. 3. vydání pražské učebnice na s. 109 a násl.

32 STAŠA, J., c. d., 4. vydání, s. 85 a násl.

33 KOPECKYY, M. Správní právo. Obecná část. Praha: C. H. Beck, 2019, s. 192-197. Ohledně pojmu „reálný akt" odkazuje na německou doktrínu.

34 Např. v cit. 1. vydání pražské učebnice na s. 77-78. 
uvedeného specifického kritéria pro jejich třídění) a soustředila se na př́kladmou charakteristiku jejich právního významu. ${ }^{35} \mathrm{~V}$ tomto ohledu byla klasifikační kaskáda zkrácena.

Změny doktríny byly ve dvou př́padech následovány změnami pozitivního práva. Správní ŕád z r. 2004,36 který je obecnou úpravou postupu správních orgánů při výkonu působnosti v oblasti veřejné správy, obsahuje ustanovení o veřejnoprávních smlouvách ${ }^{37}$ a ustanovení o opatřeních obecné povahy ${ }^{38}$.

Zákonným zakotvením opatření obecné povahy byl „potvrzen“ vznik prozatím poslední samostatné formy správní činnosti.

\section{POHLED DO SOUČASNOSTI}

Správní činnost lze chápat jako množinu veřejnoprávních úkonů vykonavatelů veřejné správy. Kaskádovité použití klasifikačních kritérií vede k rozlišování:

1. regulativních úkonů a neregulativních úkonů podle kritéria intenzity právních účinků, 2. jednostranných a vícestranných regulativních úkonů podle kritéria nezbytného počtu aktérů určujících vznik úkonem anticipované právní situace,

3. abstraktních a konkrétních jednostranných regulativních úkonů podle kritéria míry konkretizace předmětu úkonu,

4. neadresných a adresných konkrétních jednostranných regulativních úkonů podle kritéria míry konkretizace adresáta/adresátů úkonu,

5. formálních a faktických adresných konkrétních jednostranných regulativních úkonů podle kritéria stupně formalizace úkonu nebo jemu předcházejícího postupu.

Je patrné, že popsaným způsobem lze dospět ke všem „dnešním“ formám správní činnosti (abstraktní akty, opatření obecné povahy, správní akty, faktické zásahy, veřejnoprávní smlouvy, neregulativní úkony). Je ale zároveň patrné, že „,hodnoty“ těch kritérií, která představují nižší stupně kaskády, lze vztáhnout i na formy správní činnosti, pro jejichž vymezení nebyla tato kritéria použita (tak např. u všech forem správní činnosti lze hodnotit stupeň formalizace).

Plastičtější obraz forem správní činnosti může přinést transverzální použití klasifikačních kritérií, které lze označit jako maticový př́ístup. Do hry se díky němu může dostat více „nezávislých“ kritérií, jejichž aplikace povede k rozvrstvování výše uvedených klasifikátů.

S decentralizací a s deetatizací (ve smyslu výše uvedeném) veřejné správy je spojen vznik svérázných vztahů mezi různými subjekty/nositeli veřejné správy navzájem, které jsou zároveň vztahy vnějšími (jde o vztahy mezi osobami) i vnitřními (z hlediska veřejné správy jako celku). Podobné vztahy tohoto druhu, tentokrát v rámci státní správy, vznikají v souvislosti s institutem státní služby. Maticový př́stup zde umožňuje univerzální použití dalšího kritéria členění správní činnosti. Je jím charakter vztahu mezi

35 Např. v cit. 1. vydání pražské učebnice na s. 79-80.

36 Zákon č. 500/2004 Sb., správní řád.

37 Část pátá cit. správního rrádu. Jejím obsahem jsou ovšem i hmotněprávní ustanovení, která počítají též se subsidiárním uplatnění některých ustanovení občanského zákoníku.

38 Část šestá cit. správního řádu. 
původcem a adresátem úkonu. $V$ prvním plánu se podle něho rozlišují úkony směřující vůči osobám stojícím vně veřejné správy, vůči jiným osobám coby subjektům/nositelům veřejné správy, vůči osobám představujícím personální substrát daného subjektu/nositele a vůči organizačně podřízeným jednotkám daného subjektu/nositele. Znamenalo by to rovněž překonání dosavadního asymetrického přístupu $\mathrm{k}$ výkladu některých forem správní činnosti, konkrétně abstraktních aktů (za jejichž podskupinu jsou považovány vnitřní předpisy ${ }^{39}$ ) a správních aktů (u nichž se vnější působení [působnost] uvádí jako pojmový znak; ${ }^{40}$ vnější působnost však nemají subsumované správní akty, označované v pozitivním právu jako závazná stanoviska ${ }^{41}$ ). Pozitivní právo rovněž vymezuje v rámci státní správy „opozitum“ veřejnoprávní smlouvy. ${ }^{42}$

Jedním z doktrinálních východisek zkoumání forem správní činnosti je pojetí předmětného druhu správních úkonů. Formální pojetí předpokládá správní úkon jako určitou formu správní činnosti označit (explicitně názvem př́íslušné formy, popřípadě obdobně relevantním způsobem, jímž může být např. normativní odkaz na úpravu dané formy v jiném zákoně). Materiální pojetí upřednostňuje obsahovou charakteristiku úkonu včetně jeho důsledků bez ohledu na označení úkonu. $\mathrm{V}$ př́padě, že forma úkonu je zákonem předepsána nehledě na obsah, nutno upřednostnit formální pojetí (doktrinálně jde o propůjčení formy).

O pojetí správního úkonu je v současnosti významné uvažovat u abstraktních aktů, opatření obecné povahy, správních aktů a veřejnoprávních smluv. V případě

- abstraktních aktů prakticky zcela dominuje formální pojetí a doktrinálně je žádoucí, aby bylo pojetím výlučným; judikatura, která se ve sporných př́padech přiklonila $\mathrm{k}$ materiálnímu pojetí, vznikla $\mathrm{v}$ době, kdy naše pozitivní právo neznalo opatření obecné povahy; ${ }^{43}$ kriticky třeba hodnotit, že nedošlo k revizi starších úprav ve smyslu náhrady některých právních předpisů (postrádajících pravidla určená k opakovanému a v zásadě časově neomezenému používání, tj. rys abstraktnosti) opatřeními obecné povahy; ${ }^{44} \mathrm{v}$ některých př́padech se může alternativně nabízet procesualizace vydávání abstraktních aktů;, ${ }^{45}$ podrobnější rozbor může ukázat jako př́hodné rozdělit obsah stávajícího abstraktního aktu a jeho část převést do opatření obecné povahy; na druhé straně nelze nevidět, že některé úkony, které jsou zákonem označeny za opatření obecné povahy, postrádají rys konkrétnosti (konkretizaci); ${ }^{46}$

39 V cit. 9. vydání pražské učebnice na s. 130-132. Členění abstraktních aktů je ovšem ještě složitější zejména díky kategorii statutárních předpisů a (nepochybně alespoň některých) služebních předpisů, popríipadě tzv. provozních řádů.

40 V cit. 9. vydání pražské učebnice na s. 133.

41 Srov. § 149 cit. správního řádu. Vnější působnost má až finální správní akt, do něhož je závazné stanovisko subsumováno.

42 Viz $§ 160$ odst. 3 cit. správního rádu.

43 Viz např. usnesení Ústavního soudu ze dne 27. 11. 2001, sp. zn. IV. ÚS 50/02.

44 Srov. např. nařízení obce o nařízení mimořádných veterinárních opatření vydávané na návrh krajské veterinární správy podle zákona č. 166/1999 Sb., o veterinární péči a o změně některých souvisejících zákonů (veterinární zákon), ve znění pozdějších předpisů.

45 Zejména na úrovni obcí.

46 Srov. např. všeobecné oprávnění podle zákona č. 127/2005 Sb., o elektronických komunikacích a o změně některých souvisejících zákonů (zákon o elektronických komunikacích), ve znění pozdějších předpisů. 
- opatření obecné povahy správně převážilo, též vzhledem k formulační zdrženlivosti správního ráádu, ${ }^{47}$ materiální pojetí, ${ }^{48} \mathrm{v}$ pozitivním právu došlo i ke zpřesnění některých starších úprav (označení úkonu za opatření obecné povahy); ${ }^{49}$ je pravdou, že formální pojetí opatření povahy by přineslo vyšší míru právní jistoty; za zcestné lze označit úvahy o náhradě institutů, které začaly efektivně fungovat ve formě opatření obecné povahy, abstraktními akty, jimiž byly korespondující instituty podle starších úprav, ${ }^{50}$

- správních aktů je správné vycházet z materiálního pojetí, kdy nezáleží na tom, zda jde o úkon, který je výsledkem formálního řízení před správním orgánem, či nikoli; postulováním formálního korektivu materiálního pojetí se judikatura dostala do rozporu s doktrínou; ${ }^{51}$ obrat $\mathrm{k}$ lepšímu signalizuje poslední vývoj judikatury, ${ }^{52}$

- veřejnoprávních smluv lze o vhodnosti materiálního pojetí, $\mathrm{k}$ němuž vede interpretace přechodného ustanovení správního řádu ${ }^{53}$ i judikatura ${ }^{54}$, důvodně silně pochybovat; smluvní úprava veřejnoprávních vztahů má až na výjimky majetkoprávní důsledky a rozhodnout, zda u konkrétního institutu převažuje veřejnoprávní, nebo soukromoprávní stránka věci, může být obtížné až nemožné; nesnadné může být i stanovení hranice mezi veřejnoprávním a soukromoprávním obsahem smlouvy, která bude považována jak za veřejnoprávní, tak za soukromoprávní; nesrovnalosti, $\mathrm{k}$ nimž docházelo ve správní praxi a které vyústily v kompetenční spor ${ }^{55}$, kuriózně vedly v pozitivním právu až $\mathrm{k}$ výslovnému distancování se od veřejnoprávních smluv ${ }^{56}$.

Osamostatnění opatření obecné povahy sice vyplnilo nejproblematičtější „mlhavou zónu“ mezi formami správní činnosti, ale neznamená to, že by podobné zóny (do)dnes neexistovaly. ${ }^{57}$ Nepřekvapí, že se vyskytují i na okrajích oné nově vytvořené formy. Slabinou legislativního vývoje je existence opatření „svého druhu“ v úpravách přijatých

47 Viz $§ 171$ cit. správního řádu.

48 Viz nález Ústavního soudu ze dne 19. 11. 2008, sp. zn. Pl. ÚS 14/07.

49 Srov. např místní a přechodnou úpravu pravidel provozu na pozemních komunikacích podle zákona č. 361/2000 Sb., o provozu na pozemních komunikacích a o změnách některých zákonů (zákon o silničním provozu), ve znění pozdějších předpisů. K „nápravě“ došlo koncem r. 2015.

50 Diskuse týkající se formy územně plánovací dokumentace a územních opatření vyvolaná v r. 2019 v souvislosti s chystanou tzv. rekodifikací veřejného stavebního práva. Forma abstraktních aktů byla ve stavebním právu opuštěna začátkem r. 2007.

51 Viz usnesení rozšířeného senátu Nejvyššího správního soudu ze dne 18. 9. 2012, čj. 2 As 86/2010-76.

52 Viz usnesení rozšířeného senátu Nejvyššího správního soudu ze dne 17. 9. 2019, čj. 1 As 436/2017-43.

53 Viz $§ 182$ odst. 2 cit. správního řádu. Při zohlednění historie přijetí úpravy lze ovšem dospět k rozumnému výkladu, že dané ustanovení mělo na mysli pouze veřejnoprávní smlouvy podle zákona č. 128/2000 Sb., o obcích (obecní zřízení), ve znění účinném k 1. 1. 2006 (nabytí účinnosti správního řádu).

54 Viz rozsudek Nejvyššího správního soudu ze dne 26. 10. 2011, čj. 7 As 99/2011-73.

55 Viz usnesení zvláštního senátu zřízeného podle zákona o rozhodování některých kompetenčních sporů, ze dne 21. 5. 2008, čj. Konf 31/2007-82.

56 Viz § 8 odst. 5 zákona č. 194/2010 Sb., o veřejných službách v přepravě cestujících a o změně dalších zákonů.

57 K jejich možné existenci svého času STAŠA, J., c. d., 4. vydání, s. 94 (různé vztahy mezi správními akty, faktickými zásahy a regulativními úkony, jakož i neadresné faktické zásahy; na str. 96 je stručná zmínka o registračních úkonech). 
poté, co naše pozitivní právo zná opatření obecné povahy58 (úprava opatření obecné povahy měla za cíl těmto př́ípadům čelit).

Některá opatření obecné povahy mají blíže $\mathrm{k}$ abstraktním aktům, některá ke správním aktům. Konkrétnost věci se u řady z nich podává ve volnějším smyslu např. jako konkretizace zákonné úpravy v konkrétním prostoru (na konkrétním území) ${ }^{59}$ nebo v konkrétní (běžnému chodu věcí se vymykající) situaci ${ }^{60}$. V některých př́ípadech se obsah opatření obecné povahy může $\mathrm{v}$ podstatě shodovat $\mathrm{s}$ obsahem správního aktu. ${ }^{61}$

Správní akty jsou konkrétní a adresné. V pozitivním právu je adresnost popsána jako jmenovitost (jmenovité určení ${ }^{62}$ ). Striktně vzato by nemělo jít o správní akt v případě, že adresát nemůže být identifikován, což by vedlo $\mathrm{k}$ absurdním důsledkům „,rozdvojení“ úkonu (na správní akt s identifikovaným adresátem) a na opatření obecné povahy (v př́ipadě neznámého adresáta); řešením je zachování formy správního aktu a modifikace postupu vůči neznámému adresátovi63. Na újmu konkrétnosti a/nebo adresnosti není hromadnost (co do předmětu ${ }^{64}$ nebo co do adresátů ${ }^{65}$ ) správního aktu. ${ }^{66}$

Jiná je podoba adresnosti faktických zásahů (některých faktických pokynů, velké většiny bezprostředních zásahů). Jde o fyzickou adresnost na místě prítomného adresáta úkonu. Př́ípadná formální identifikace je až následná. Rozlišení může být námětem dalšího členění faktických zásahů.

Některé faktické zásahy (faktické pokyny) mohou být dodatečně formalizovány. Úprava vydávání správních aktů $\mathrm{v}$ řízení na místě vyvolala nedomyšlenou snahu dodatečnou formalizaci vytěsňovat/nahradit tak faktický pokyn správním aktem). ${ }^{67} \mathrm{Ne}$ domyšlenost spočívá v „odhlédnutí “ od otázky oprávněného recipienta projevu vůle vykonavatele veřejné správy. Nedorozumění může vyvolávat fakt, že míra formalizace různých faktických pokynů je značně rozdílná.

Dalším citlivým místem je rozhraní správních aktů a subordinačních veřejnoprávních smluv. ${ }^{68}$ Proč rozlišovat mezi veřejnoprávní smlouvou a správním aktem, který není výsledkem řízení před správním orgánem, ale předpokladem jehož vydání je kon-

58 Srov. (judikatorní) závěr o povaze politiky územního rozvoje podle zákona č. 183/2006 Sb., o územním plánování a stavebním řádu (stavební zákon). Viz usnesení Nejvyššího správního soudu ze dne 18. 11. 2009, čj. 9 Ao 3/2009-59.

59 Př́íkladem je územní plán podle cit. stavebního zákona.

60 Př́ikladem je úprava, omezení, popř́ípadě zákaz obecného nakládání s povrchovými vodami podle zákona č. 254/2001 Sb., o vodách a o změně některých zákonů (vodní zákon), ve znění pozdějších předpisů.

61 Srov. regulační plán na žádost a územní rozhodnutí o umístění stavby nebo využití území podle cit. stavebního zákona.

62 Viz $§ 9$ cit. správního řádu.

63 Srov. $§ 25$ odst. 1 a $\S 32$ odst. 2 písm. d) cit. správního rádu.

64 Př́íkladem je územní rozhodnutí o umístění souboru staveb podle cit. stavebního zákona.

65 Př́íkladem je správní akt vydaný v řízení s velkým počtem účastníkủ (§ 144 cit. správního řádu).

${ }^{66} \mathrm{~V}$ poněkud jiné souvislosti se o hromadných správních aktech zmiňuje D. Hendrych (např. v cit. 2. vydání pražské učebnice na s. 58).

67 Rozdíl mezi dodatečně formalizovaným faktickým pokynem a správním aktem vydaným v řízení na místě je patrný při srovnání opatření inspektora podle zákona č. 64/1986 Sb., o České obchodní inspekci, ve znění pozdějších předpisů, a zákona č. 146/2002 Sb., o Státní zemědělské a potravinářské inspekci, ve znění pozdějších předpisů. K tomu srov. § 143 cit. správního řádu. Možnost oznámit projev vůle správního orgánu „komukoli“, kdo se na daném místě nachází, neřeší jeho právní proveditelnost pro př́ípad, že se tam nenachází nikdo.

68 Srov. § 161 a navazující ustanovení cit. správního řádu. 
sensuální prostředí (souhlas dotčených osob)? ${ }^{69}$ Je rovněž otázkou, zda by možný zákonem předvídaný obsah subordinační smlouvy neměl být širší („,bohatší‘) ve srovnání s možným obsahem správního aktu, který je veřejnoprávní smlouvou nahrazován. ${ }^{70}$ Význam může mít blíže členit subordinační veřejnoprávní smlouvy v závislosti na tom, zda je subjekt/nositel veřejné správy coby strana smlouvy zavázán po uzavření smlouvy poskytnout určité plnění, či nikoli.

Srovnání forem správní činnosti ukazuje na mezery v otázkách vlastností správních úkonů71 a vad správních úkonů (přiliš ,hrubá“ se zdá již sama škála vad, ${ }^{72}$ některé vady některých forem nejsou teorií obecně akceptovány [nicotnost abstraktních aktů] nebo rozpracovány [nicotnost veřejnoprávních smluv]). „Na druhém konci“ jsou mezery v otázkách kompenzace újmy způsobené vadným správním úkonem (ve vztahu k jednotlivým formám se explicitní úprava týká pouze správních aktů [diskusní u nich zůstává režim kompenzace újmy způsobené nicotným správním aktem]; podle judikatury se nevztahuje na abstraktní akty; u opatření obecné povahy a u veřejnoprávních smluv se nabízí analogie se správními akty), ale i bezvadným výkonem působnosti/ pravomoci (není obecně řešeno vůbec).

Modernizace veřejné správy evokuje možnosti automatizace některých správních úkonů (konkrétně některých správních aktů, některých faktických pokynů a některých neregulativních úkonů). S automatizací souvisí otázka „depersonalizace veřejné správy“ (kdo je původcem úkonu?), prakticky významná např. kvůli regresním úhradám následujícím po kompenzaci újmy způsobené vadným úkonem ze strany subjektu/nositele veřejné správy. ${ }^{73}$ Mají mít tyto trendy vliv na členění forem správní činnosti?

Za členěním regulativních úkonů silně pokulhává členění úkonů neregulativních. Kromě již zmíněné charakteristiky jejich právního významu se vlastně omezuje na výčet př́kladů. Jisté ospravedlnění vyplývá (objektivně) z jejich rozmanitosti, jakož i (subjektivně) z pochopitelné snahy právní teorie soustredit pozornost na úkony, které jsou ,právně významnějšš‘“. Proti naposled uvedenému lze namítnout, že v souvislosti s konceptem dobré správy význam těchto úkonů roste a dále poroste. Možným přístupem je členit neregulativní úkony podle stejných kritérií jako úkony regulativní, vyjasnit by bylo zapotřebí otázky terminologické (terminologie vylučující záměnu

69 Př́íkladem je územní souhlas podle cit. stavebního zákona.

70 Příkladem „,chudé“ subordinační veřejnoprávní smlouvy je ta, která nahrazuje stavební povolení. Obsahově „,bohatší“ je veřejnoprávní smlouva o akreditaci podle zákona č. 22/1997 Sb., o technických požadavcích na výrobky, ve znění pozdějších předpisů.

71 U správních aktů jde např. o otázku platnosti a vyčerpání platnosti, o otázku tzv. materiální právní moci nebo o otázku možnosti vydat nový správní akt. K některým otázkám zmíněným v odborné literatuře (z poslední doby) viz např. KOPECKÝ, M. Význam materiální právní moci a rei iudicatae v právu správním. Právník, 2016, roč. 155, č. 10, s. 843-862, nebo STAŠA, J. Peripetie právní moci a vykonatelnosti. In: VAČOK, J., - HAVELKOVÁ, M. - DŽAČKOVÁ, M. (eds.). Právoplatnost'správnych rozhodnutíprávna istota vs. legalita. Bratislava: Univerzita Komenského v Bratislave, Právnická fakulta, 2018, s. 188-195.

$72 \mathrm{~K}$ pokusu o rozš́írení/diferenciaci pojmu „nesprávnosti“ viz STAŠA, J. Vady (správních aktů) a čas. In: VAČOK, J. - HAVELKOVÁ, M. (eds.). Determinanty právnej úpravy prieskumu individuálnych správnych aktov. Bratislava: Univerzita Komenského v Bratislave, Právnická fakulta, 2019, s. 47-59.

73 K problému depersonalizace viz STAŠA, J. On possible depersonalization of originator of administrative acts. In: SLÁDEČEK, V. et al. Current Development Tendecies in Public Administration. Olomouc: Iuridicum Olomoucense, 2012, s. 187-195. 
s regulativními úkony) a zkoumat by bylo zapotřebí, zda by s ohledem na různorodost právního významu bylo možné s těmito kritérii vystačit a dospět $\mathrm{k}$ „užitečnému“ členění.

V širším kontextu správní činnosti „,vůbec“, dodejme, že pojetí správní činnosti jako množiny správních (= veřejnoprávních) úkonů a pojetí formy správní činnosti není jediné možné (nabízí se jeho rozšíření; v prvé řadě by šlo o zahrnutí exkluzívních soukromoprávních jednání, $\mathrm{k}$ nimž jsou na základě zákona autorizovány osoby soukromého práva, ${ }^{74}$ ve druhé řadě pak veřejným právem obligatorně modifikovaná soukromoprávní jednání osob veřejného práva ${ }^{75}$ ). S větší dávkou fantazie možno kalkulovat i s některými veřejnoprávními úkony adresátů veřejné správy (inspirativní v tomto ohledu je tzv. třetí typ veřejnoprávních smluv ${ }^{76}$ ). Stejně tak nelze za jedině možné považovat vymezení forem správní činnosti výlučně z hlediska hmotného práva ${ }^{77}$ (procesní formou je napřs. správní rízení; to zahrnuje řadu subforem ${ }^{78}$ ) nebo stejnorodosti (řadu institutů lze chápat jako „směs“ heterogenních správních úkonů, která v souhrnu naplňuje funkci předmětného institutu; v tomto smyslu lze použít označení „funkční forma“"79). A jestliže by se teorie správního práva nebo administrativistika věnovaly problematice metod veřejné správy, došlo by $\mathrm{k}$ oživení úvah o formách jejich uplatňování.

\section{KONTURY VÝHLEDU}

\section{VE VZTAHU K SAMOTNÉ TEORII}

Další zkoumání problematiky správní činnosti a jejích forem by mělo přispět $\mathrm{k}$ vyplnění přetrvávajících bílých míst $\mathrm{v}$ teorii správního práva, především správního práva hmotného.

„Prưrezezove“" se nabízí orientovat pozornost na úvahy o

- identifikaci a sledování přechodových zón mezi stávajícími formami správní činnosti,

- významu dopadů uplatnění kritéria vztahu mezi původcem a adresátem úkonu na stávající formy správní činnosti,

- možnostech ,automatizace“ některých forem správní činnosti a důsledcích s tím související „depersonalizace“,

- formulaci a/nebo př́padném „zpodrobněni“ škály vad jednotlivých forem správní činnosti,

74 Př́íkladem je autorizovaný inspektor podle cit. stavebního zákona.

75 Př́íkladem jsou právní jednání veřejného zadavatele podle zákona č. 134/2016 Sb., o veřejných zakázkách.

76 Ustanovení § 162 cit. správního rádu.

77 O „trhlinách“ svědčí např. zmínky o procesních správních aktech (v 9. vydání pražské učebnice na s. 134) nebo zahrnutí exekučních úkonů a zajištovacích úkonů mezi faktické zásahy (tamtéž na s. $188-189)$.

78 Viz zvláštní řízení v části třetí cit. správního řádu.

79 Př́íkladem je institut správního dozoru jako „směs“ správních úkonů různé povahy. 
- kompenzaci újmy způsobené vadnými úkony, popřípadě újmy vzniklé v souvislosti s bezvadným výkonem pravomoci/působnosti ve vztahu k jednotlivým formám správní činnosti,

- možnostech komplexnějšího pohledu na správní činnost pomocí konstrukce procesních forem činnosti a/nebo tzv. funkčních forem,

- možném rozšíření pojmu „správní činnost“ zahrnutím veřejnoprávně významných nebo veřejnoprávně modifikovaných soukromoprávních jednání vykonavatelů veřejné správy,

- vhodnosti rozšiřrení pojmu ,správní činnost“ o některé veřejnoprávní úkony adresátů veřejné správy 80 .

Ohledně jednotlivých forem správní činnosti se pak nabízejí úvahy o

- hledání hranice mezi opatřeními obecné povahy a hromadnými správními akty včetně rozlišení mezi konkrétností opatření obecné povahy a konkrétností správního aktu,

- pojmovém zpřesnění „konkrétnosti“ a „jmenovitosti“ úkonu, týkající se zejména správních aktů činěných vůči neznámým esenciálním adresátům a/nebo faktických zásahů,

- syntéze poznatků o vlastnostech správních aktů,

- účincích subsumovaných správních aktů včetně srovnání s modelovými alternativami subsumpce,

- rozdílu mezi dodatečně formalizovaným faktickým pokynem a správním aktem vydaným na místě,

- možnosti principiálního prosazování formálního pojetí veřejnoprávních smluv s tím, že takto neoznačená smlouva se bude řídit pořadem soukromého práva, a s př́ípadnou výjimkou smluv uzavíraných mezi osobami veřejného práva, jejichž obsahem není žádné ustanovení majetkoprávní povahy,

- předpokladech opodstatněnosti obsahově „chudých“ subordinačních veřejnoprávních smluv a př́ípadném obohacování jejich obsahu,

- hledání a prověřování možností systematičtějšího členění neregulativních úkonů. Nesud’me přitom, zda k řešení zbývá méně, či více než toho, co je hotovo.

\section{VE VZTAHU TEORIE A PRAXE}

Teoretické poznatky o formách správní činnosti mají značná potenciál využití v legislativě. Limitujícím faktorem je nedostatečná koncepčnost a koordinovanost př́ipravy a projednávání „,správních“ zákonů81 ${ }^{81}$ nejednou ovlivněná voluntaristickým zadáním $\mathrm{a} /$ nebo uspěchaností harmonogramu prací ${ }^{82}$ a často korunovaná tolerancí $\mathrm{k}$ chaotickým lobbisticky prosazovaným změnám předloh $\mathrm{v}$ závěrečné etapě procesu ${ }^{83}$. Zda,

80 Blíže viz STAŠA, J. Veřejnoprávní úkon, nebo soukromoprávní jednání? In: POMAHAČ, R. (ed.). Veřjné a soukromé právo (správní a trestní aspekty). Praha: Univerzita Karlova, Právnická fakulta, 2017, s. $182-192$.

81 Mimochodem - „správních“ zákonů je naprostá většina.

82 Neblahým př́íkladem je již zmíněná tzv. rekodifikace veřejného stavebního práva.

83 Opět př́íklad ze stavebního práva - tzv. velká novela cit. stavebního zákona z r. 2017 a pozměňovací návrhy týkající se závazných stanovisek. 
nakolik a kdy dojde k potlačení uvedených neduhů, je otázkou. Náprava by umožnila organičtější komunikaci mezi teorií a praxí, jejich symbiózu. Na jedné straně by mohla praxe teorii více naslouchat a zúročit její upotřebitelné výstupy. Na druhé straně by praxe mohla pro teorii formulovat rozumná zadání a přispět tak ke smysluplnému vyplnění mezer teoretického poznání.

JUDr. Ing. Josef Staša, CSc.

Právnická fakulta Univerzity Karlovy

stasa@prf.cuni.cz 